Original Research Paper

\title{
GO-NGO Support in Selected Char Areas of Sirajganj District in Bangladesh: Impact on Crop Profitability and Farmers' Income Generation
}

\author{
${ }^{1}$ Md. Monirul Islam, ${ }^{2}$ Arifa Jannat and ${ }^{1}$ Aurup Ratan Dhar \\ ${ }^{1}$ Department of Agricultural Economics, \\ ${ }^{2}$ Institute of Agribusiness and Development Studies, \\ Bangladesh Agricultural University, Mymensingh-2202, Bangladesh
}

Article history

Received: 08-05-2017

Revised: 19-06-2017

Accepted: 23-10-2017

Corresponding Author: Md. Monirul Islam Department of Agricultural Economics, Bangladesh Agricultural University, Mymensingh-2202, Bangladesh E-mail: monir.bau_96@yahoo.com

\begin{abstract}
The study was carried out to elucidate the GO-NGO support on farmers' income generation in selected char areas of Sirajganj district. Following purposive sampling technique, a total of 60 farmers (30 nonsupported and 30 GO-NGO supported) were selected for the study. Descriptive statistics, mathematical and statistical analyses were used to analyze the collected data from field survey method. The average benefit cost ratio (BCR) of crop farming for non-supported farmers was 1.70 and for GO-NGO supported farmers it was 1.80 indicated that crop farming was more profitable under GO-NGO supported farmers. The double difference estimates for total income in the year of 2012 and 2014 was Tk. 14046.8 which was statistically significant. Ravallion test result also picturized that, income was increased by Tk. 10404.0 for the support obtained from the different GOs and NGOs. From logit model it was found that farm size, household size, education level of the household head and farm income had significant influence on adopting GO-NGO supports in farming practices. Farmers expressed their opinion about the lack of transportation facilities, low price of output, etc. as major problems. Transportation and communication facilities should be improved in the study areas, government social safety net programmes should be enhanced to support the farmers in char areas and compulsory primary education programme for both male and female should be implemented.
\end{abstract}

Keywords: GO-NGO Support, Char, Profitability, Income Generation

\section{Introduction}

Bangladesh is furnished with diverse agricultural seasons, which allows the farmers cultivating two and sometimes more than two crops on the same field. Nearly 5\%, as well as about 10 million people of Bangladesh live on the char narrowed as 7200 square kilometers (Kelly and Chowdhury, 2002). The economy of the people of river basin areas is highly dependent on agriculture. Majority of the char residents are engaged in different farming systems which were also different from the main land. A number of social protection interventions such as, social safety net programmes, various training facilities, awareness campaign, etc. have been providing by the government and non-government organizations (GOs and NGOs) to the poorest households in char areas. Different GOs and NGOs have tried to overcome their vulnerable condition by increasing the productivity of income-generating activities (IGAs) according to their time, interest, geographical area, and needs. It is promising that GOs and NGOs like Polli Karma Sahayak Foundation (PKSF), Bangladesh Rural Development Board (BRDB), Grammen Bank (GB), Bangladesh Rural Advancement Committee (BRAC), Char Livelihood Programme (CLP), etc. have taken initiatives to make vulnerable situation tolerable.

Government of Bangladesh has strategic plan and program for increasing the agricultural production of char people, improvement of their livelihood status and also to mitigate various problems faced by them. The employment opportunities of char dwellers are even less diversified than the ones of other rural poor in the district. Different NGOs are working in the char areas to provide applied knowledge and links to sources of information, to contribute to the poverty alleviation and community development through various support and 
services. Basically, the poor people of the bottom stratum of the society, having no capital and little access to resources are the inhabitants of those char areas. Without the intervention of GO-NGOs, the situation would be more problematic and challenging.

The study can be supported by a modest number of literatures which are: Islam et al. (2011) discussed socioeconomic analysis of alternative farming systems in improving livelihood security of small farmers in selected areas of Bangladesh and reported that small farmers included more enterprises in farm practices to have better food security, higher income and improving livelihood; Hasan and Sultana (2011) observed that most of the respondents were middle aged, had medium to big families, were mostly illiterate and different types of vegetables were being grown by the respondents including spinach, bitter gourd, cowpea, etc. in the summer season and red amaranth, brinjal, tomato, etc. in the winter season; Uddin (2004) aimed at evaluating the production levels, costs and benefits, profitability in relation to farm size and resource use of various enterprises that comprise integrated farming in Bangladesh and revealed that there was a big gap in profit by farm size among integrated farms with a similar pattern of enterprise composition; Mahamud (2011) examined the livelihood of the people of Boyer char in Noakhali district of Bangladesh, under the intervention of Char Development and Settlement Project (CDSP) by the government of Bangladesh and aimed to evaluate whether and to what extent the intervention brought a change in the livelihood of the people.

The above review indicates that most of the studies discussed about different farming systems, their respective profitability and farmers' livelihood condition but most of them are not in the char areas. To minimize the research gap, the present study will examine the socioeconomic status of char farmers, comparative profitability of non-supported and GONGO supported farming practices and its impacts on changes in farmers' monetary income.

The specific objectives of the study are:

- To examine the comparative profitability analysis of GO-NGO supported farmers

- To investigate the key determinants of the adoption of different supports and services provided by the GOs and NGOs

\section{Materials and Methods}

\section{Study Areas and Sample Size}

A total of 60 farmers (30 from non-supported and 30 from GO-NGOs supported both in Belkuchi and Chauhali upazila in Sirajganj district) were selected by following purposive sampling technique for data collection where different GO-NGOs organizations are working for the improvement of the lot of char people. This survey has covered ten numbers of crops along with non-farm activities for one year. The data were collected from the selected farmers through direct interview on recall basis. Moreover, Focus Group Discussions (FGD) and Key Informant Interviews (KII) were conducted. The primary data were collected on ten different competitive crops grown in a calendar year (Karim et al., 2014) namely, Aus, Aman, Till, Boro, Jute, Wheat, Dhoincha, Mustard, Maskalai and Khesarikala. Secondary information sources like different books, handouts, publications, notifications, published and unpublished documents of Government of Bangladesh and its different non-government organizations were also taken into consideration.

\section{Analytical Techniques}

The data were analyzed with an amalgam of descriptive statistics (i.e., sum, mean, percentages, etc.), mathematical (profitability analysis) and statistical (difference-in-differences method, Ravallion test and logit model) analyses.

\section{Profitability of Different Crop Farming}

Per hectare profitability of crop production, from the view point of individual farmers was measured in terms of gross return, gross margin, net return, benefit cost ratio (undiscounted) and profitability ratio. The formula needs for the calculation of profitability are discussed below:

\section{Gross Return (GR)}

The following equation was used to estimate GR:

$$
G R=P \times Q
$$

Where:

$G R=$ Gross return

$P=$ Sale price of the product (Tk.)

$Q=$ Yield per hectare (unit)

\section{Gross Margin (GM)}

Gross margin was calculated by:

$$
G M=G R-T V C
$$

Where:

$$
\begin{aligned}
& G M=\text { Gross margin } \\
& G R=\text { Gross return } \\
& T V C=\text { Total Variable Cost }
\end{aligned}
$$

\section{Net Return (NR)}

The following algebraic form of net return was used for estimation:

$$
N R=G R-(T F C+T V C)
$$


Where:

$N R=$ Net return

$G R=$ Gross return

$T F C=$ Total fixed cost $(\mathrm{Tk}$.

$T V C=$ Total variable cost $(\mathrm{Tk}$.

\section{Benefit Cost Ratio (BCR)}

The formula of calculating BCR (undiscounted) was as follows:

$$
B C R=G R \div(T F C+T V C)
$$

Where:

$B C R=$ Benefit cost ratio

$T F C=$ Total fixed cost $(\mathrm{Tk}$.

$T V C=$ Total variable cost (Tk.)

\section{Profitability Ratio}

The formula used for estimating profitability ratio was as follows:

$$
\text { Profitability ratio }=N R_{N S} \div N R_{S}
$$

Where:

$N R_{N S}=$ Net return of non-supported farmers; and

$N R_{S}=$ Net return of GO-NGO supported farmers

\section{Impact of GO-NGO Support on Farmers' Income Generation}

\section{Ravallion Test}

The impacts of GO-NGO support on crop farming were measured by using comparison of the non-supported and GO-NGO supported farmers' income generation with the help of Ravallion test. The formula used for estimation defined by Ravallion (2008) was as follows:

$$
I=\frac{1}{n} \sum_{i=1}^{n}\left(O_{i-}^{T} O_{i}^{C}\right)
$$

Where:

$I=$ Average impact

$N=$ Sample size

$I=$ Sample units

$O=$ Value of the interpretable impact indicator

$T=$ Treatment group

$C=$ Control group

The paired sample $t$ test was applied to test the significance of relevant parameters.

\section{Difference-In-Differences (DID) Method}

DID was constructed to measure what would have happened if the GO-NGO support had not been available, and to find the difference between the previous and present situation after the support provided. The following formula was used for estimation:

$$
D I D=\left(S_{1}-N_{1}\right)-\left(S_{0}-N_{0}\right)
$$

Where:

$S_{0}=$ 'Before' situation of GO-NGO supported farmers

$S_{1}=$ 'After' situation of GO-NGO supported farmers

$N_{0}=$ 'Before' situation of non-supported farmers

$N_{1}=$ 'After' situation of non-supported farmers

\section{Determinants of Adopting GO-NGO Support in Different Farming Operations}

To determine the factors that have significant influence on the adoption of GO-NGO support in the study areas, logit regression model of the following form was used:

$$
\begin{aligned}
Y & =\ln \left(\frac{P_{i}}{1+P_{i}}\right)=\beta_{0}+\beta_{1} X_{1}+\beta_{2} X_{2}+\beta_{3} X_{3} \\
& +\beta_{4} X_{4}+\beta_{5} X_{5}+\beta_{6} X_{6}+\varepsilon_{i}
\end{aligned}
$$

where, $P_{i}$ is the probability of adoption and non-adoption of GO-NGO support; and $P_{i}=0$ indicates non-adoption and $P_{i}=1$ indicates adoption. Dependent variable (i.e., binary variable): $Y=$ Probability of adoption of GONGO support. Independent variables: $X_{1}=$ Farm size (ha); $X_{2}=$ Age of household head (years); $X_{3}=$ Household size (number); $X_{4}=$ Educational level of household head (years of schooling); $X_{5}=$ Farm income (Tk.); $X_{6}=$ Non-farm income (Tk.); $\beta_{0}=$ Intercept; $\beta_{1}$ to $\beta_{6}=$ Regression coefficients of the dependent variables and $\varepsilon=$ Disturbance term.

According to Gujarati (1995), the marginal probabilities of the key determinants of adopting GONGO support were estimated based on expressions derived from the marginal effect of the logit model which was estimated as:

$$
d Y / d X=\beta_{i}\left\{P\left(1-P_{i}\right)\right\}
$$

where, $\beta_{\mathrm{i}}=$ Estimated logit regression coefficient with respect to the $\mathrm{i}^{\text {th }}$ factor; and $P_{i}=$ Estimated probability of a farm household adoption status.

\section{Results and Discussion}

\section{Socioeconomic Status of the Char Farmers}

Socioeconomic status of the farmers in char areas is represented in Table 1. Average crop area was 0.21 ha for non-supported and for GO-NGO supported farmers it was 0.25 ha. Average numbers of livestock and poultry birds were $3.83,4.27$ and 5.35, 7.65 for non-supported and GO-NGO supported farmers, respectively. 
Table 1. Socioeconomic status of the char farmers

\begin{tabular}{lcc}
\hline Particulars & Non-supported farmers & GO-NGO supported farmers \\
\hline Crop area (ha) & 0.21 & 0.25 \\
Livestock (no.) & 3.83 & 4.27 \\
Poultry (no.) & 5.35 & 7.65 \\
Agroforestry (no.) & 5.15 & 5.48 \\
Family size (no.) & 5.20 & 6.30 \\
Age (16-55 years) (\%) & 51.60 & 61.90 \\
Average literacy rate (\%) & 53.30 & 64.30 \\
Occupational status & & \\
Farming (\%) & 23.30 & 30.00 \\
Farming + handloom (\%) & 40.00 & 20.00 \\
Rented/mortgaged/leased-in land (\%) & 55.20 & 60.50 \\
Dependency ratio (no.) & 2.25 & 2.52 \\
\hline
\end{tabular}

Source: Field survey, 2015

Average number of agroforestry was 5.15 and 5.48 for non-supported and GO-NGO supported farmers, respectively. Most of the farmers fell within the working age group of 16 to 55 years and it was 51.6 and $61.9 \%$, respectively for non-supported and GO-NGO supported farmers in char areas. Average family size of nonsupported and GO-NGO supported farmers was 5.2 and 6.3 which was higher than the national average of 4.53 (HIES, 2010). Average literacy rate of GO-NGO supported farmers $(64.3 \%)$ was higher than the nonsupported $(53.3 \%)$ farmers and it also exceeded the national average literacy rate (57.9\%) (BER, 2013). On an average, $23.3 \%$ farmers were engaged in crop farming in case of non-supported whereas, which was $30.0 \%$ for GO-NGO supported farmers. Rented/mortgaged/leasedin land contained the maximum portion of the total farm size, and it was 55.23 and $60.50 \%$ for non-supported and GO-NGO supported farmers, respectively. In the study areas, economically working and earning persons were 2.25 and 2.52 for non-supported and GO-NGO supported farmers, respectively.

\section{Credit and Training Utilization Pattern}

The GO-NGO supported farmers have spent the loan they took mainly for the farming and non-farming activities. From Table 2 it is apparent that 44.5 and $55.5 \%$ loaned money were utilized for agricultural and non- agricultural purposes. Being poor, they used their credit in some non-agricultural purposes such as small business, daughter marriage, food consumption (during flood period), etc. There are different GO-NGO organizations working in char areas that provide loans and training to the farmers for various purposes. Farmers of char areas generally borrowed money from BRDB under the project of 'one house one farm', ASA, MMS, GKS, CLP, CARITAS, NDP, BRAC, CARE, Bangladesh, etc. They also provide the farmers facilities with safe drinking water, sanitation and hygiene, and involvement with various income generating activities.
They also provide various training and technical assistance in agricultural activities such as, rice plantation, vegetable cultivation, cattle and goat rearing, poultry production, etc. for both men and women in the study areas. Sometimes different expert teams also visited the char areas and gave some valuable advice to cope with the natural calamities.

\section{Profitability of Different Crop Farming}

\section{Variable Cost}

Average cost of human labor was estimated at $\mathrm{Tk}$. 14525 and Tk. 16334 per hectare for non-supported and GO-NGO supported farmers, respectively in char areas. Farmers usually used power tiller on the basis of rent. Average power tiller cost was estimated at Tk. 6424 and Tk. 6299 per hectare for non-supported and GO-NGO supported farmers, respectively. Most of the farmers used purchased seeds for different crop production from the local market. Costs of different seed per hectare was at Tk. 2139 for non-supported and Tk. 2397 was estimated in case of GO-NGO supported farmers in the study areas. Farmers applied following kinds of fertilizers such as, urea, TSP, MoP, DAP and others, the cost of which were Tk. 3035, 1570, 462, 310 and 402 for non-supported farmers and for GO-NGO supported farmers it were Tk. 3145, 1670, 555, 245 and 345 per hectare, respectively. It is seen that cost of fertilizers for crop farming were estimated at Tk. 5779 and Tk. 5730 per hectare for non-supported and GO-NGO supported farmers, respectively. In the study areas, all farmers were dependent on deep tubewell and shallow tubewell for irrigation. Average irrigation costs were Tk. 4560 and Tk. 4698 per hectare for non-supported and GO-NGO supported farmers, respectively. Costs of insecticides were found to be Tk. 206 and Tk. 148 in case of nonsupported and GO-NGO supported farmers, respectively. It is observed that total variable cost varied from year to year. It was Tk. 33635 for non-supported farmers and on the other hand, it was estimated at Tk. 35609 for GONGO supported farmers (Tables 3 and 4). 
Table 2. Uses of credit by the GO-NGO supported farmers

\begin{tabular}{lll}
\hline Purposes & Amount (Tk.) & Percentage of credit used (\%) \\
\hline Agricultural activities & 8835.0 & 44.5 \\
Non-agricultural activities & 11065.0 & 55.5 \\
Total & 20000.0 & 100.0 \\
\hline
\end{tabular}

Source: Field survey, 2015

Table 3. Cost of production per hectare for non-supported farmers

\begin{tabular}{|c|c|c|c|c|c|c|c|c|c|c|c|}
\hline Cost items & Aus & Aman & Till & Boro & Jute & Wheat & Dhoincha & Mustard & Maskalai & $\begin{array}{l}\text { Khesari } \\
\text { kalai }\end{array}$ & Average \\
\hline \multicolumn{12}{|l|}{ Variable cost } \\
\hline Human labor & 29572 & 20461 & 9818 & 19702 & 9615 & 8113 & 10382 & 11352 & 12074 & 14167 & 14526 \\
\hline Power tiller & 4749 & 12152 & 2072 & 9585 & 4315 & 7211 & 4464 & 14034 & 1661 & 4002 & 6425 \\
\hline Seed/seedlings & 4631 & 2664 & 309 & 2950 & 1226 & 3691 & 748 & 390 & 3019 & 1770 & 2140 \\
\hline \multicolumn{12}{|l|}{ Fertilizer cost } \\
\hline Urea & 5552 & 1430 & 788 & 5980 & 2750 & 3290 & 2345 & 7865 & 1190 & 1765 & 3035 \\
\hline TSP & 2876 & 463 & 100 & 2985 & 670 & 1865 & 200 & 2455 & - & 345 & 1570 \\
\hline $\mathrm{MoP}$ & 1476 & - & - & 1198 & - & 1142 & - & 1598 & - & - & 462 \\
\hline DAP & 670 & - & - & 780 & - & 456 & - & 1186 & - & - & 310 \\
\hline Others & 450 & 20 & - & 111 & 157 & 1097 & 362 & 1866 & 89 & 218 & 402 \\
\hline Total fertilizer cost & 11024 & 1913 & 888 & 11054 & 3577 & 7850 & 2907 & 14970 & 1279 & 2328 & 5779 \\
\hline Irrigation & 45602 & - & - & - & - & - & - & - & - & - & 4560 \\
\hline Insecticides & 1907 & - & - & - & - & 159 & - & - & - & - & 207 \\
\hline $\begin{array}{l}\text { A. Total variable cost } \\
\text { Fixed cost }\end{array}$ & 97484 & 37190 & 13087 & 43291 & 18733 & 27024 & 18501 & 40747 & 18033 & 22266 & 33636 \\
\hline Lease value & 8732 & 4366 & 4366 & 8732 & 8732 & 8732 & 4366 & 4366 & 4366 & 4366 & 6113 \\
\hline Interest on operating cost & 4549 & 1736 & 611 & 2020 & 874 & 1261 & 863 & 1902 & 842 & 1039 & 1570 \\
\hline B. Total fixed cost & 13282 & 6102 & 4977 & 10753 & 9607 & 9993 & 5230 & 6268 & 5208 & 5405 & 7682 \\
\hline C. Total cost $(A+B)$ & 110766 & 43292 & 18064 & 54043 & 28340 & 37018 & 23730 & 47014 & 23240 & 27672 & 41318 \\
\hline
\end{tabular}

Source: Authors' estimation, 2015

Table 4. Cost of production per hectare for GO-NGO supported farmers

\begin{tabular}{|c|c|c|c|c|c|c|c|c|c|c|c|}
\hline Cost items & Aus & Aman & Till & Boro & Jute & Wheat & Dhoincha & Mustard & Maskalai & $\begin{array}{l}\text { Khesari } \\
\text { kalai }\end{array}$ & Average \\
\hline \multicolumn{12}{|l|}{ Variable cost } \\
\hline Human labor & 30562 & 18793 & 10603 & 29192 & 21374 & 11412 & 11222 & 9238 & 10501 & 10449 & 16335 \\
\hline Power tiller & 4375 & 13315 & 4374 & 11228 & 4966 & 9942 & 4476 & 6928 & 925 & 2463 & 6299 \\
\hline Seeds/seedlings & 4077 & 3243 & 324 & 3368 & 1525 & 5328 & 771 & 411 & 3367 & 1563 & 2398 \\
\hline \multicolumn{12}{|l|}{ Fertilizer cost } \\
\hline Urea & 4567 & 1458 & 1456 & 4678 & 2890 & 4789 & 2347 & 7345 & 865 & 1386 & 3145 \\
\hline TSP & 2765 & 455 & 356 & 2564 & 876 & 2979 & 200 & 2765 & - & 472 & 1670 \\
\hline MoP & 1655 & - & 234 & 1198 & 230 & 1465 & - & 765 & - & - & 555 \\
\hline DAP & 670 & - & - & 795 & - & 357 & - & 634 & - & - & 245 \\
\hline Others & 499 & 20 & 218 & 121 & 229 & 793 & 362 & 1655 & 108 & 83 & 345 \\
\hline Total fertilizer cost & 10156 & 1933 & 2264 & 9356 & 4225 & 10383 & 2909 & 13164 & 973 & 1941 & 5730 \\
\hline Irrigation & 46985 & - & - & - & - & - & - & - & - & - & 4698 \\
\hline Insecticides & 1488 & - & - & - & - & - & - & - & - & - & 149 \\
\hline $\begin{array}{l}\text { A. Total variable cost } \\
\text { Fixed cost }\end{array}$ & 97643 & 37283 & 17566 & 53144 & 32090 & 37065 & 19378 & 29741 & 15766 & 16416 & 35609 \\
\hline Lease value & 8732 & 4366 & 4366 & 8732 & 8732 & 8732 & 4366 & 4366 & 4366 & 4366 & 6113 \\
\hline Interest on operating cost & 4557 & 1740 & 820 & 2480 & 1498 & 1730 & 904 & 1388 & 736 & 766 & 1662 \\
\hline B. Total fixed cost & 13289 & 6106 & 5186 & 11212 & 10230 & 10462 & 5270 & 5754 & 5102 & 5132 & 7774 \\
\hline C. Total cost $(A+B)$ & 110932 & 43389 & 22752 & 64356 & 42320 & 47527 & 24649 & 35495 & 20868 & 21548 & 43384 \\
\hline
\end{tabular}

Source: Authors' estimation, 2015

\section{Fixed Cost}

The value of owned land was calculated as 'opportunity cost' principle. Per hectare lease value was estimated at Tk. 6112 in crop farming both for nonsupported and GO-NGO supported farmers. Lease value was estimated for one year period of time based on prevailing rate. Interest on operating cost was charged for a period of four months at the rate of $\mathrm{Tk} .14 .0 \%$ per annum. Interest on operating cost incurred Tk. 1569 and Tk. 1661 per hectare for non-supported and GO-NGO supported farmers, respectively. Total fixed cost for nonsupported was estimated at Tk. 7682 and Tk. 7774 for GONGO supported farmers per hectare (Tables 3 and 4). 


\section{Total Cost}

Total cost was calculated by summing up total variable cost and total fixed cost. Average total cost was Tk. 41318 and Tk. 43384 for non-supported and GONGO supported farmers per hectare, respectively (Tables 3 and 4).

\section{Gross Return (GR)}

Average gross return was Tk. 65635 and Tk. 76870 per hectare for non-supported and GO-NGO supported farmers, respectively (Tables 5 and 6).

\section{Gross Margin (GM)}

Gross margin of crop farming were estimated at Tk. 32000 and Tk. 41261 for non-supported and GO-NGO supported farmers per hectare, respectively in the study areas (Tables 5 and 6).

\section{Net Return (NR)}

Tables 5 and 6 exhibit that net return of crop farming were Tk. 24317 and Tk. 33486 for non-supported and GO-NGO supported farmers per hectare, respectively (Tables 5 and 6).

\section{Benefit Cost Ratio (BCR)}

Average benefit cost ratio (BCR) of crop farming for non-supported farmers was 1.7 indicating that crop farming is profitable. On the other hand, the BCR was 1.8 for GO-NGO supported farmers which indicate that, the crop farming is more profitable than the nonsupported one (Tables 5 and 6).

\section{Profitability Ratio}

Table 7 represents that the profitability ratio of nonsupported farmers and GO-NGO supported farmers was 0.73; which implies that non-supported farmers earned Tk. 73 from crop farming while GO-NGO supported farmers earned Tk. 100. The result was significant at $5 \%$ level.

\section{Impact on GO-NGO Support on Farmers' Income Generation}

An analysis of income sources adds further insight into the income generation process. There were two sources of income for both non-supported and GO-NGO supported farmers. These sources were farm and nonfarm income. After the intervention, the income of the GO-NGO supported farmers was increased because of credit facilities, extension services, supervision and monitoring of the field worker. Table 8 depicts that average annual income of non-supported and GONGO supported farmers in 2014 were Tk. 102672.1 and Tk. 128076.1, respectively. Table 8 also illustrates that average yearly income of nonsupported and GO-NGO supported farmers in 2012 were Tk. 89200.0 and Tk. 103700.0, respectively.

Table 5. Profitability of different crops for non-supported farmers

\begin{tabular}{|c|c|c|c|c|c|c|c|c|c|c|c|}
\hline Crops & Aus & Aman & Till & Boro & Jute & Wheat & Dhoincha & Mustard & Maskalai & $\begin{array}{l}\text { Khesari } \\
\text { kalai }\end{array}$ & Average \\
\hline Output & 156 & 50 & 20 & 102 & 32 & 94 & 4236 & 90 & 31 & 32 & 484 \\
\hline Price & 728 & 808 & 1459 & 887 & 1750 & 837 & 7 & 925 & 1708 & 1178 & 1029 \\
\hline Return & 116001 & 39618 & 29080 & 90671 & 56665 & 78419 & 28405 & 83065 & 52904 & 38392 & 61322 \\
\hline By-product & 3612 & 12806 & - & 16571 & 10148 & - & - & - & - & - & 4314 \\
\hline Gross Return (GR) & 119613 & 52424 & 29080 & 107242 & 66813 & 78419 & 28405 & 83065 & 52904 & 38392 & 65636 \\
\hline $\begin{array}{l}\text { Gross margin } \\
(\mathrm{GM}=\mathrm{GR}-\mathrm{TVC})\end{array}$ & 22129 & 15234 & 15993 & 63951 & 48079 & 51395 & 9904 & 42318 & 34872 & 16126 & 32000 \\
\hline Net Return (GR-TC) & 8847 & 9132 & 11016 & 53198 & 38473 & 41401 & 4675 & 36051 & 29664 & 10721 & 24318 \\
\hline $\begin{array}{l}\text { Benefit-Cost Ratio } \\
(\mathrm{BCR}=\mathrm{GR} / \mathrm{TC})\end{array}$ & 1.08 & 1.21 & 1.61 & 1.98 & 2.36 & 2.12 & 1.20 & 1.77 & 2.28 & 1.39 & 1.70 \\
\hline
\end{tabular}

Source: Authors' estimation, 2015

Table 6. Profitability of different crops for GO-NGO supported farmers

\begin{tabular}{|c|c|c|c|c|c|c|c|c|c|c|c|}
\hline Crops & Aus & Aman & Till & Boro & Jute & Wheat & Dhoincha & Mustard & Maskalai & $\begin{array}{l}\text { Khesari } \\
\text { Kalai }\end{array}$ & Average \\
\hline Output & 157 & 53 & 30 & 112 & 57 & 104 & 4188 & 95 & 36 & 27 & 486 \\
\hline Price & 838 & 772 & 1568 & 850 & 1760 & 864 & 6 & 920 & 1541 & 1171 & 1029 \\
\hline Return & 131446 & 41621 & 47248 & 95434 & 99490 & 87281 & 25428 & 87547 & 56037 & 31572 & 70310 \\
\hline By-product & 5374 & 13759 & - & 33683 & 12783 & - & - & - & - & - & 6560 \\
\hline Gross Return (GR) & 136820 & 55380 & 47248 & 12911 & 112273 & 87281 & 25428 & 87547 & 56037 & 31572 & 76870 \\
\hline $\begin{array}{l}\text { Gross margin } \\
(\mathrm{GM}=\mathrm{GR}-\mathrm{TVC})\end{array}$ & 39177 & 18097 & 29682 & 75973 & 80183 & 50216 & 6050 & 57806 & 40271 & 15156 & 41261 \\
\hline $\begin{array}{l}\text { Net return } \\
(\mathrm{GR}-\mathrm{TC})\end{array}$ & 25888 & 11991 & 24496 & 64761 & 69954 & 39754 & 779 & 52052 & 35169 & 10024 & 33487 \\
\hline $\begin{array}{l}\mathrm{BCR} \\
(\mathrm{BCR}=\mathrm{GR} / \mathrm{TC})\end{array}$ & 1.23 & 1.28 & 2.08 & 2.01 & 2.65 & 1.84 & 1.03 & 1.68 & 2.69 & 1.47 & 1.80 \\
\hline
\end{tabular}

Source: Authors' estimation, 2015 
Table 7. Profitability ratio

\begin{tabular}{lllll}
\hline Farmers' categories & Net return & Profitability ratio & p-value & t-value \\
\hline Non-supported farmers & 24318 & $0.73^{* *}$ & 0.026 & 2.262 \\
GO-NGO supported farmers & 33487 & & & \\
\hline
\end{tabular}

Source: Authors' estimation, 2015; Note: ${ }^{* *}$ Significant at 5 percent level

Table 8. Average annual income of the farmers

\begin{tabular}{|c|c|c|c|c|}
\hline \multirow[b]{2}{*}{ Sources of income } & \multicolumn{2}{|c|}{ Non-supported farmers } & \multicolumn{2}{|c|}{ GO-NGO supported farmers } \\
\hline & Amount (Tk.) & Percentage $(\%)$ & Amount (Tk.) & Percentage $(\%)$ \\
\hline \multicolumn{5}{|l|}{ In 2014} \\
\hline A. Total farm income & 71605.4 & 69.74 & 89326.1 & 69.74 \\
\hline B. Total non-farm income & 31066.7 & 30.26 & 38750.0 & 30.26 \\
\hline C. Total income $(\mathrm{A}+\mathrm{B})$ & 102672.1 & 100.00 & 128076.1 & 100.00 \\
\hline \multicolumn{5}{|l|}{ In 2012} \\
\hline A. Total farm income & 60800.0 & 68.16 & 68100.0 & 65.67 \\
\hline B. Total non-farm income & 28400.0 & 31.84 & 35600.0 & 34.33 \\
\hline C. Total income $(\mathrm{A}+\mathrm{B})$ & 89200.0 & 100.00 & 103700.0 & 100.00 \\
\hline
\end{tabular}

Source: Field survey, 2015

In addition to assessing the impact of GO-NGO support and services on income generation in the study areas, the authors' also estimated the change in total farm income, total non-farm income as well as total income behavior of the GO-NGO supported and nonsupported farmers over 2012 to 2014 periods. DID estimates showed that for non-supported farmers, total income difference was Tk. 13472.1 and for GO-NGO supported farmers, it was Tk. 24376.1. The estimated result of Double-Difference (DID) method was Tk. 10904 in the year 2012 and 2014 which is statistically significant (Table 9).

The result of Ravallion test shows that the annual average income per farm was increased from Tk. 117672.1 to Tk. 128076.1 because of the GO-NGO support. The income was increased by the amount of Tk. 10404.0 due to the support obtained from the different GO and NGO organizations working in the study areas. The finding was significant at $10 \%$ probability level and verified by the value of t-statistic (Table 10).

\section{Determinants of Adopting GO-NGO Support by the Farmers}

The result of logit regression model showed that four out of six variables included in the model were significant in explaining the variation of adopting GONGO support in farming practices. The significant variables were: farm size, household size, education level of the household head and farm income of the sample farm households in char areas (Table 11). The estimated equation was as follows:

$$
\begin{aligned}
Y_{i}= & -2.542-3.164 X_{1}+0.0056 X_{2} \\
& +0.327 X_{3}+1.196 X_{4}+1.141 X_{5}+0.046 X_{6}
\end{aligned}
$$

\section{Farm Size}

The farm size of the farmers has negative coefficient and it was 3.164, which was significant at $10 \%$ level. One unit increase in the farm size will decrease the probability of adopting GO-NGO support in farming practices by 3.16 unit, keeping other factors constant (Table 11).

\section{Household Size}

Household size has also positive coefficient and it was 0.327 , which was also statistically significant at $10 \%$ level. One unit increase in the household size will increase the probability of adopting GO-NGO support in farming practices by 0.33 unit, keeping other factors constant (Table 11).

\section{Education Level of Household Head}

The parameter estimates of education level carry a positive result which is 1.196 and is statistically significant at $5 \%$ level. One unit increase in the education level of the household head will increase the probability of adopting GO-NGO support in farming practices by 1.196 unit, keeping other factors constant (Table 11).

\section{Farm Income}

This result implies that households' annual average farm income was positive which was 1.141 and significant at $10 \%$ level. If other things remain constant, one unit increase in the level of farm income will increase the probability of household to be adopted GO-NGO support in farming systems by 1.14 unit (Table 11).

\section{Marginal Effects Subsequent to Logit Model}

The results of marginal effects subsequent to logit model are shown below:

$$
Y=\operatorname{Pr}(\text { type of farmers })(\text { predict })=0.492
$$


Table 9. Double difference estimates for income generation

\begin{tabular}{|c|c|c|c|c|c|}
\hline Outcome variables & $\begin{array}{l}\text { Non-supported } \\
\text { farmers }\end{array}$ & $\begin{array}{l}\text { GO-NGO } \\
\text { upported farmers }\end{array}$ & Difference & t- statistic & p-value \\
\hline Total farm income in 2012 & 60800.0 & 68100.0 & 7300.0 & 15.12 & 0.0000 \\
\hline Total farm income in 2014 & 71605.4 & 89326.1 & 17720.7 & 11.93 & 0.0532 \\
\hline $\begin{array}{l}\text { Difference in total farm } \\
\text { income (2014-2012) }\end{array}$ & 10805.4 & 21226.1 & 10420.7 & 11.30 & 0.1945 \\
\hline Total non-farm income in 2012 & 28400.0 & 35600.0 & 7200.0 & 11.50 & 0.1341 \\
\hline Total non-farm income in 2014 & 31066.7 & 38750.0 & 7683.3 & 16.36 & 0.0000 \\
\hline $\begin{array}{l}\text { Difference in total non-farm } \\
\text { income (2014-2012) }\end{array}$ & 2666.7 & 3150.0 & 483.3 & 14.78 & 0.0000 \\
\hline Total income in 2012 & 89200.0 & 103700.0 & 14500.0 & 17.93 & 0.0000 \\
\hline Total income in 2014 & 102672.1 & 128076.1 & 25404.0 & 53.22 & 0.0000 \\
\hline $\begin{array}{l}\text { Difference in total income } \\
(2014-2012)\end{array}$ & 13472.1 & 24376.1 & 10904.0 & 58.94 & 0.0000 \\
\hline
\end{tabular}

Source: Authors' estimation, 2015; Note: Total farm incomes in 2012 and in 2014 are considered as before-after situation

Table 10. Ravallion test result (in Tk./farm)

\begin{tabular}{lll}
\hline Sources of income & Non-supported farmers (Tk.) & GO-NGO supported farmers (Tk.) \\
\hline Total farm income & 81605.4 & 89326.1 \\
Total non-farm income & 36066.7 & 34750.0 \\
Total income & 117672.1 & 128076.1 \\
Change in total income & $10404.0\left(2.02^{*}\right)$ & \\
\hline
\end{tabular}

Source: Authors' estimation, 2015; Note: *Significant at $10 \%$ level

Table 11. Estimates of the logit regression model

\begin{tabular}{llllll}
\hline Variables & Coefficient $(\mathrm{Y})$ & Std. Err. & $\mathrm{z}$ & $\mathrm{P}>\mathrm{z}$ & $95 \%$ Confidence Interval \\
\hline Constant & -2.542 & 1.981 & -2.12 & 0.051 & -6.931 \\
Farm size $\left(\mathrm{X}_{1}\right)$ & $-3.164^{*}$ & 1.551 & -1.77 & 0.072 & -6.521 \\
Age of household head $\left(\mathrm{X}_{2}\right)$ & 0.056 & 0.051 & 1.21 & 0.276 & -0.045 \\
Household size $\left(\mathrm{X}_{3}\right)$ & $0.327^{*}$ & 0.169 & 1.79 & 0.097 & -0.077 \\
Education level of & $1.196^{* *}$ & 0.631 & 1.92 & 0.059 & -0.043 \\
household head $\left(\mathrm{X}_{4}\right)$ & & & & & -0.321 \\
Farm income $\left(\mathrm{X}_{5}\right)$ & $1.141^{*}$ & 0.746 & 1.53 & 0.101 & -0.915 \\
Non-farm income $\left(\mathrm{X}_{6}\right)$ & 0.046 & 0.490 & 0.10 & 0.926 & \\
\hline
\end{tabular}

Source: Authors' estimation, 2015; Note: **Significant at 5 percent level and *significant at 10 percent level

Table 12. Estimates of the marginal effect

\begin{tabular}{|c|c|c|c|c|c|c|}
\hline Variables & $\mathrm{dy} / \mathrm{dx}$ & Std. Err. & $\mathrm{z}$ & $\mathrm{P}>\mathrm{z}$ & $\begin{array}{l}95 \% \text { Con } \\
\text { Interval }\end{array}$ & $\mathrm{X}$ \\
\hline Farm size $\left(\mathrm{X}_{1}\right)$ & $-0.771^{*}$ & 0.412 & -1.87 & 0.061 & -1.579 & 0.037 \\
\hline Age of household head $\left(X_{2}\right)$ & 0.012 & 0.010 & 1.11 & 0.265 & -0.009 & 0.032 \\
\hline Household size $\left(X_{3}\right)$ & $0.078^{*}$ & 0.047 & 1.67 & 0.095 & -0.014 & 0.170 \\
\hline $\begin{array}{l}\text { Education level of } \\
\text { household head }\left(\mathrm{X}_{4}\right)\end{array}$ & $0.285^{* *}$ & 0.141 & 2.02 & 0.044 & 0.008 & 0.562 \\
\hline Farm income $\left(\mathrm{X}_{5}\right)$ & $0.285^{*}$ & 0.186 & 1.53 & 0.101 & -0.080 & 0.650 \\
\hline Non-farm income $\left(\mathrm{X}_{6}\right)$ & 0.012 & 0.123 & 0.09 & 0.925 & -0.023 & 0.252 \\
\hline
\end{tabular}

Source: Authors' estimation, 2015; Note: **Significant at 5\% level and *significant at 10\% level

The result of marginal effect shows that the farm size of the farmers has a negative value of $\mathrm{dY} / \mathrm{dX}$ and it was 0.771 unit, which was significant at $10 \%$ level. It indicated that the predicted probability of adoption was 0.771 unit lower for the individual in higher farm size than for one who was smaller one, remaining all other factors the same. The marginal effect on the probability of adopting GO-NGO support in different farming practices was 0.078 unit greater for large household size than the smaller one, keeping all other factors constant. The predicted probability of adoption was 0.285 unit higher for the individual in better education level than for one who was less educated, holding all other factors equal. The predicted probability of adoption was 0.285 unit higher for the individual in higher farm income than for one who was smaller farm income earner, assuming other things unchanged (Table 12). 


\section{Constraints of Farming Systems in Char Areas}

Majority of the farmers pointed out that lack of transportation problem was the main problem in the study areas. A number of the farmers said that, low price of output was an important problem in the study areas. Basically, the reason behind this was the lack of transportation facilities. High prices of different inputs were also one of the most important problems which was stated by both non-supported and GO-NGO supported farmers the study areas. Lack of education and training facilities were also identified as foremost difficulties for GO-NGO supported farmers compared to the non-supported farmers.

\section{Conclusion}

For increasing farm productivity and income, credit can play a very important role. The GO-NGO supported farmers have used their credit loan especially for the purpose of agricultural and non-agricultural activities. Major amount of loaned money the utilized for agricultural purposes included purchasing of agricultural inputs and maintenance. Different crop farming was much more profitable for GO-NGO supported farmers than the non-supported farmers. Income generation was increased due to the intervention of different support agencies for GO-NGO supported farmers compared to the nonsupported farmers.

\section{Policy Implications}

Increase in farm size, household size, level of education and farm income enable farmers to renovate their production system through GO-NGO supports would be more helpful to increase the production level of char farmers. To overcome these stated constraints, GOs and NGOs should take initiatives to carry out the suggestions given by the local farmers to achieve self-sufficiency in production of food as well as in consumption.

\section{Acknowledgement}

The authors are thankful to Ministry of Science and Technology (MoST), Government of the People's Republic of Bangladesh to grant National Science and Technology Fellowship, 2014-15 for funding partly to conduct this study. The authors also express their earnest gratitude to the respondents and stakeholders of the study areas for their alliance and assistance in conducting surveys and collecting the data and information.

\section{Author's Contributions}

Md. Monirul Islam: Designed, collected and checked the analyzed data; prepared the draft manuscript and approved the final manuscript.
Arifa Jannat: Coordinated the study, analyzed the data and supervised the draft manuscript.

Aurup Ratan Dhar: Reviewed the draft manuscript, prepared the draft manuscript and contributed in data interpretation.

\section{Ethics}

This article is original and contains unpublished material. The corresponding author confirms that all of the other authors have read and approved the manuscript and no ethical issues involved.

\section{References}

BER, 2013. Ministry of Finance, Government of the Peoples' Republic of Bangladesh.

Hasan, S.S. and S. Sultana, 2011. Food and economic security through homestead vegetable production by women in flood affected char land. The agriculturists. Sci. J. Krishi Found., 9: 44-53. DOI: 10.3329/agric.v9i1-2.9478

HIES, 2010. Preliminary report on household income and expenditure survey, Bureau of Statistics Division, Ministry of Planning, Government of the People's Republic of Bangladesh, Dhaka.

Islam, S., M.T. Uddin, M. Akteruzzaman, M. Rahman and M.A. Haque, 2011. Profitability of alternate farming systems in Dighapota haor area of Netrokona district. Progress. Agric., 22: 223-239.

Karim, M.M., M.S.U. Bhuiya and S.M.A. Hossain, 2014. Crop diversification and intensification through community vegetable production trial in a village of Dingaputa haor. J. Environ. Sci. Natural Res., 7: 59-61.

Kelly, C. and M.H.K. Chowdhury, 2002. Poverty, disasters and the environment in Bangladesh: A quantitative and qualitative assessment of causal linkages.

Mahamud, M.S., 2011. Intervention of char development and settlement project: does it make a difference in people's livelihood at Boyer char in Bangladesh. Department of General and Continuing Education, North South University, Bangladesh.

Ravallion, M., 2008. Evaluating Anti-Poverty Programs. In: Handbook of Development Economics, Paul Schultz, T. and J.A. Struass, (Eds.), Elsevier, pp: 3787-3846.

Uddin, M.T., 2004. Economic analysis of integrated farming by agricultural enterprise in Mymensingh district of Bangladesh. J. Rural Development, 16: 40-49. 